\title{
Maintaining and Enhancing Students' Collaborative Learning in a Japanese EFL Higher Education Context
}

\author{
Masayo Kanno ${ }^{1}$
}

\begin{abstract}
Amid the COVID-19 pandemic, there has been a huge shift towards digital forms of education. Although Japan has never gone into full lockdown, students have been strictly kept at home and socially isolated from classroom learning for extended periods. Teachers were urged to create online teaching and learning resources and began to consider the most suitable technologies to teach their courses. This paper reports on a teacher's ongoing efforts to develop and deliver distancelearning English as a foreign language (EFL) courses in a higher education context. Drawing on a view that learning is social development, the researcher focuses on the concept of social presence in peer-to-peer communication that could enhance collaborative learning in a virtual classroom. Synchronous distance learning courses were developed utilising a text-messaging application and collaborative text-editing software with the aim to establish a communicative learning space. Analysis into the students' interactions in Slack workspaces - a text messaging applicationindicated a variety of interpersonal, open, and cohesive communication that signalled psychological closeness in the virtual learning environment. Group discussion sessions revealed that students could feel connected to each other in the synchronous EFL courses, which demonstrated the robustness of social interaction despite physical distancing. Major difficulties lay in three areas: technology, the nature of the task, and some students' task preferences. These three areas need to be addressed when designing and delivering a distance learning course.
\end{abstract}

Keywords: Collaborative learning, Computer-mediated learning, Distance education, Peer support, Social presence

\footnotetext{
${ }^{1}$ Integrated Engineering Department, National Institute of Technology, Sendai College, Japan, mkanno@sendainct.ac.jp
} 


\section{Background}

\section{Introduction}

The unpredictable COVID-19 outbreak has brought about periods of social distancing that keep students from classroom communication. In Japan, where a new school year starts at the beginning of April, there have been a number of changes in the start dates for the 2020 school year. In late March, colleges and universities announced the postponement by a few weeks in favour of the government's policy (MEXT, 2020a). As an increasing number of clusters of infections were reported throughout Japan at the beginning of April, these institutions pushed the starting date further back and began considering distance education for the whole semester (MEXT, 2020b).

While Japan never went with a strict lockdown, the government's declaration of a state of emergency put students into educational isolation for extended periods. Most Japanese higher education institutions assume on-site face-to-face modes of delivery, which has made it extremely difficult to quickly switch to distance learning modes (MEXT, 2020c; 2020d). Students were not only physically isolated at homes but also socially isolated away from their classmates. This isolation urged English as a foreign language (EFL) teachers to explore effective ways of online teaching using synchronous videoconferencing tools such as Zoom, Google Meet, and Microsoft Teams.

When designing distance learning courses, it is necessary to consider what types of communication are possible on what devices. In Japan, mobile phone users have outnumbered PC users, and this trend is more obvious among younger generations (Ministry of Internal Affairs and Communication, 2019). Given the fact that a great majority of late-teens access the Internet from their phones (Cabinet Office, 2020), online course development needs to take mobile phone users into consideration. Besides real-time videoconferencing software, mobile texting has a potential as an accessible mode of communication. While text messaging tends to be considered distracting in the physical classroom environment (Chen \& Yan, 2016), it can be a vital communication tool for informal peer-to-peer interaction that enables both synchronous and asynchronous communication (Wei \& Wang, 2010).

This paper is a report of an ongoing exploration of the development of distance EFL courses for Japanese college students. Taking a sociocultural approach to language learning, it sees learning as human development through learners' engagement in social interaction (Lantolf, Thorne \& Poehner, 2015). It proposes and examines an approach to pursue collaborative and communicative classroom activities that could bring students together virtually while staying apart physically. 
Social presence is discussed as a key concept to consider better ways to provide students with a virtual but an immediate learning space. This paper intends to discuss the possibilities and difficulties of conducting a learner-centred distance-learning course that helps facilitate collaborative learning.

\section{Literature review}

Social presence has been a key concept in pursuit of effective distance education. It refers to the degree to which a person is perceived as a "real person" in the interaction and interpersonal relationships (Gunawardena \& Zittle, 1997). This is as important as learning content because computer-mediated interaction lacks interpersonal effects in comparison with face-to-face communication. One of the frequently discussed areas is teaching presence, which can possibly facilitate students' classroom engagement. Teachers' experience and confidence with online teaching predicted higher teaching presence in synchronous distance learning (Rehn, Maor, \& McConney, 2016). This account of social presence assumes synchronous lecturing and teacher-led instruction that are more teacher-centred and less student-oriented than asynchronous delivery (Murphy, Rodríguez-Manzanares, \& Barbour, 2011).

Interestingly in Japan, where distance education had long been a great minority, a guideline explicitly mentions students' active involvement as one of the requirements for a distance mode of course delivery (MEXT, 2001). The guideline explains synchronous and asynchronous learning styles that can be viewed as equivalent to face-to-face classes. While the former is grouped as synchronous interactive distance education, the latter is elaborated with regard to two types of classroom communication: teacher-student interaction, and student-student interaction. This distinction indicates the importance of interpersonal communication among students along with instructional communication when designing distance learning courses in a higher education context.

In a similar vein, collaborative learning experience is also an essential element to enhance social presence in a virtual classroom. This aspect of social presence appears to be crucial, as it accommodates learners' self-efficacy and engagement in learning tasks (Blaine, 2019). In order to gain a better understanding of non-verbal online group communication, Garrison (2011: 37-39) conceptualised three categories of social interaction: interpersonal, open, and cohesive communication. Interpersonal communication involves affective responses, self-disclosure outside class, and use of humour. Open communication refers to reciprocal and respectful interaction that aims to carry on conversation and show engagement in group work. Cohesive communication 
involves greetings and messages that signal a sense of group commitment, which is the dynamic state that social presence intends to achieve. These categories allow investigation into social presence in student-student classroom interaction with an aim to help establish a collaborative learning space where learners feel connected to each other (d'Alessio et al., 2019).

Previous studies that sought for students' engagement in group activities reported the effectiveness of using technology tools in enhancing group communication and collaboration. For instance, synchronous online collaborative writing could increase students' engagement in text-editing tasks, which resulted in better academic performance than students in a face-to-face learning environment (Han \& Li, 2019). The use of a text-messaging application, such as Slack, can possibly facilitate students' mutual support. This easy-to-use computer-mediated communication helps to create a virtual communicative atmosphere in which students could visualise their own contribution to the group and solve a problem without a teacher's involvement (Tuhkala \& Kärkkäinen, 2018; Zhang, Meng, de Pablos, \& Sun, 2019).

Active engagement in online group discussion may be positively related to students' academic performance, but this requires some caution. Joksimović, Gašević, Kovanović, Riecke, and Hatala (2015) drew on Garrison's (2011) concept of social presence and revealed that some indicators of online group collaboration predicted better academic performance. This finding echoed the report of Palmer, Holt, and Bray (2008) that active participation in group discussion assignments contributed to improving the final grades. However, students who only superficially reacted to others' posts demonstrated insufficient learning outcomes, which indicated the significance of students' awareness of constructive discussion as well as instructional intervention (d'Alessio et al., 2019; Joksimović et al, 2015). Some students tend to be resistant to online collaborative activities, which could be related to their discomfort in engaging in student-led tasks that were incompatible with their expectations towards rote-learning (Kear, Jones, Holden, \& Curcher, 2016).

\section{Theoretical framework}

This paper draws on a sociocultural theory that views knowledge as being co-constructed through interaction between the individuals and the society. It assumes that individuals are fundamentally social and their mental development is mediated by social interaction (Lantolf et al., 2015; Vygotsky, 1978). In this view, students play an active role in their own learning when they socially interact and build knowledge together (John-Steiner \& Mahn, 1996).

The present study explores social presence in a learning context where students are physically distant from each other (Gunawardena \& Zittle, 1997). It specifically examines three categories of 
social interaction that enhance social presence in student-student communication (Garrison, 2011). Through designing and delivering an EFL course with virtual collaborative activities, it intends to seek answers for the following research questions:

1. Are there any instances of social presence seen in students' interaction in a synchronous virtual classroom?

2. Does a group chat through a text messaging application facilitate students' collaboration?

3. What difficulties entail synchronous distance course delivery using multiple apps?

\section{Methodology}

EFL test preparation courses: The focal EFL courses started on 20 April at a national college of technology in Japan. The students' English proficiency was between beginner and intermediate levels. The EFL courses are mandatory, aiming to get the engineering-major students prepared for Japan's most popular test of English, the Test of English for International Communication (TOEIC) The online mode of course delivery was originally thought as tentative for a few weeks, which was then decided to continue until June. The institution is now considering to offer distance learning courses for the whole semester.

At the time of writing this paper, the researcher had officially taught the courses for two weeks, which corresponds with Weeks 2 and 3 (Table 1). Week 1 was a preparatory class conducted as a pilot with voluntary participation. Of a total of 94 students at age 17-19 registered to the courses, 87 synchronously participated in Week 2, and four students asynchronously joined later. Three students did not join Week 2 activities, but two of them reacted to the teacher's follow-up messages and contributed to the Week 3 class.

Distance learning course design: Multiple modes of communication tools were used to deliver the EFL courses. Although the nature of test practice lends itself to asynchronous self-study, a synchronous mode of course delivery was chosen in an attempt to provide real-time study sessions to make sure all the students were actively involved in the coursework. An emphasis was placed on collaborative learning through social interaction, in accordance with the government's guideline that encourages student-to-student communication (MEXT, 2001).

As the courses were at the very beginning of the 2020 school year, Weeks 2 and 3 consisted of several introductory tasks. These were developed to address the following elements:

1. To get students familialised with the structure of the TOEIC test

2. To develop a collaborative virtual learning environment 
3. To investigate which systems and applications are useful

Table 1 shows the contents of each class, with systems and applications used in each activity. All activities were designed to accommodate smartphone users. According to the institution's policy, Blackboard Learn was used as a rigid interface between teacher and students, which helped present coursework instructions, learning materials, and hyperlinks to resources.

Table 1: Class Contents, Systems, and Applications

\begin{tabular}{|c|l|l|}
\hline Week & Class contents & Systems / Applications \\
\hline 1 & Preparatory week & Blackboard Learn \\
\hline 2 & Course overview & Blackboard Learn \\
\cline { 2 - 3 } & $\begin{array}{l}\text { Group work: PPT slides editing "What is the } \\
\text { TOEIC test?" "Why is it popular?" }\end{array}$ & Slack, PowerPoint online \\
\cline { 2 - 3 } & Short videoconference sessions* & Microsoft Teams* \\
\hline \multirow{2}{*}{3} & Reading Section practice test & Slackboard Learn, \\
\cline { 2 - 3 } & Group work: Vocabulary building practice & Microsoft Teams* \\
\cline { 2 - 3 } & Short videoconferencing sessions* \\
\cline { 2 - 3 } & Feedback & \\
\hline
\end{tabular}

*Not mandatory

Coursework involved individual test practice and group work through crowd-sourcing applications. Online collaboration software, such as PowerPoint slides and Excel spreadsheets, was used to enable collaborative text-editing tasks. Short videoconferencing and text-chatting sessions were conducted at the beginning and the end of each class time, which were not mandatory but open to those who were available.

To facilitate synchronous classroom communication, the course utilised Slack. This application provides a space for group discussion, in which students can work collaboratively through textmessaging and file- and photo-sharing. These workspaces were also accessible by the teacher so that she could give assistance, share upcoming issues in class, and see which students were actively contributing to the task (Zhang, et al., 2019).

Data collection and analysis: Qualitative data were collected through class observation and group discussion. Students' peer-to-peer text messaging in Slack workspaces was monitored during class and reviewed after class. There were two group discussion sessions conducted right after Week 3 
classes ended, in which students voluntarily shared constructive feedback on the format of the course. Each session lasted for 20 and 15 minutes, respectively. Informed consent was received from the participants as well as the institution administration.

The text messages were manually coded and analysed for themes with a focus on social presence indicated in the peer-to-peer interaction. Garrison's (2011) three categories of social presencenamely, interpersonal, open, and cohesive communication-were drawn on as a guideline to analyse the text data.

\section{Findings}

Peer interaction via Slack: A variety of indicators of social presence were observed in text messages at Slack workspaces. Students' interaction did not genuinely aim at the coursework, but rather social and communicative elements were also involved. This section reports on the students' interaction that indicated the three social presence categories: interpersonal communication that involves affective factors, open communication that is built through trust and acceptance, and cohesive communication that sustains commitment to an e-learning group (Garrison, 2011).

First, interpersonal communication was frequently seen throughout the class time. The left image in Figure 1 illustrates that the interaction began with initial greetings, which were followed by an apology “ごめんなさい (I'm sorry)” from one student who was unable to join the previous week’s activity. As the group was getting ready to work, one student asked "Doesn't seem everyone is here but we're starting now??" Then another member responded with self-disclosure: "Sorry I'm late, I just woke up.”, which was replied with a sense of humour “おはよう笑(good morning, smile)”. The right image in Figure 1 shows interaction between two students in a different group. One student was unable to edit an Excel file and kept telling “ごめん (sorry)” with emojis. The other was willing to help out, which response ended also with a smiling emoji, $\mathrm{d}\left({ }^{\wedge} \mathrm{w}^{\wedge}\right) \mathrm{b}$. 


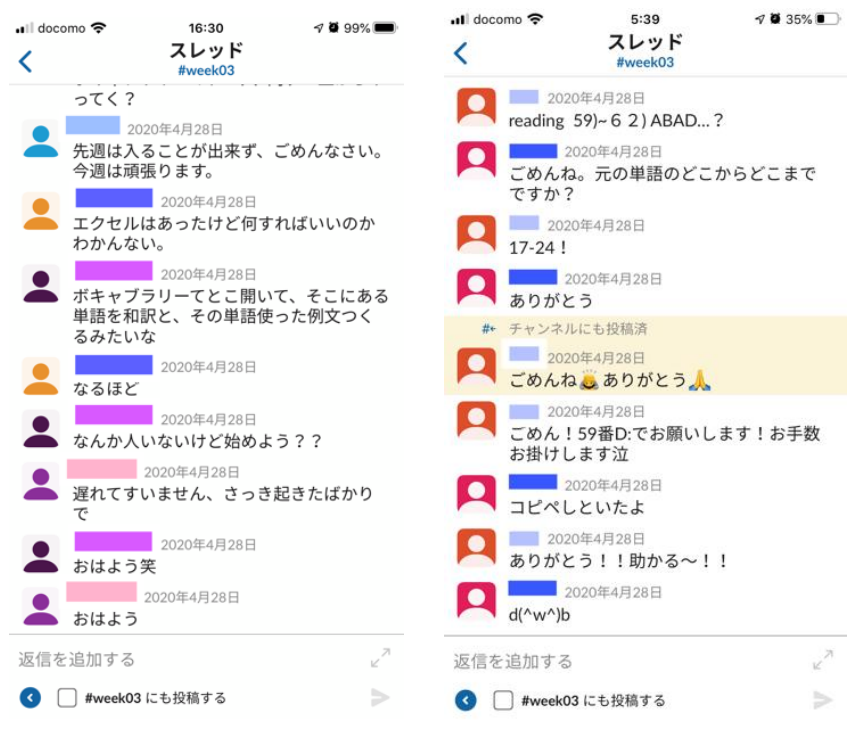

Figure 1: Interpersonal Communication

Second, a number of instances of open communication were seen throughout the text data (Figure 2). In the left image, one student asked about what device they were using. Once he learned most group members were using a smartphone, he voluntarily offered to work on PowerPoint slides with his PC. The image in the middle illustrates the process of group agreement, in which students clicked on a like button to other members' contributions and suggestions when they were finishing up the task. However, not all interaction reached an agreement. The third image shows interactive responses when two of them could not access the working file. They asked another student to do all the work for them, perhaps making little effort to solve the technical problem themselves. This group did not complete the task during the class time.

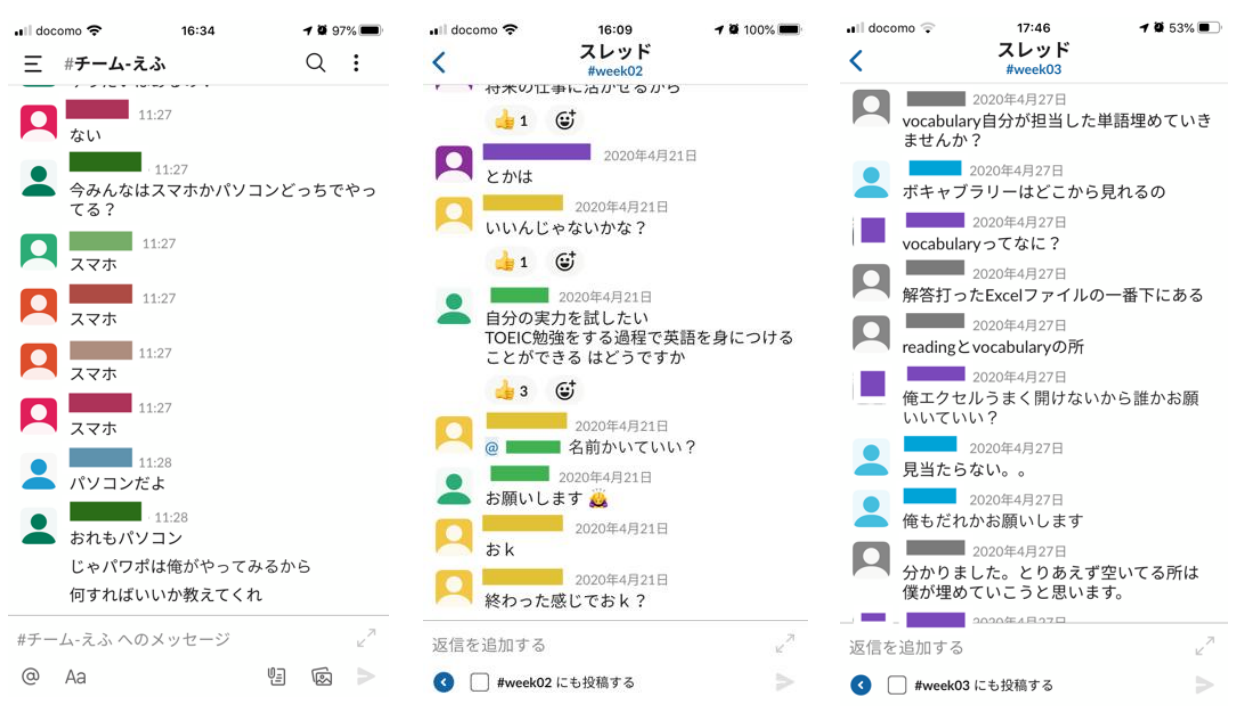

Figure 2: Open Communication 
Third, cohesive communication was achieved and demonstrated in all groups, such as greetings and messages that indicated group solidarity. Students began and finished their group work with greetings. They greeted each other saying "good morning" while trying to make sure that others were in the discussion space. A sense of group commitment was also seen; for example, some students made their own group's channel and invited their members. Images in Figure 3 illustrate interactions that signalled e-learning group cohesion. The left image shows conversation where students were helping each other in finding ways to access the group's channel. In the right image, one student was reminding others of the time of the next videoconferencing session so that they all could gain some additional information and thus contribute to the group work.

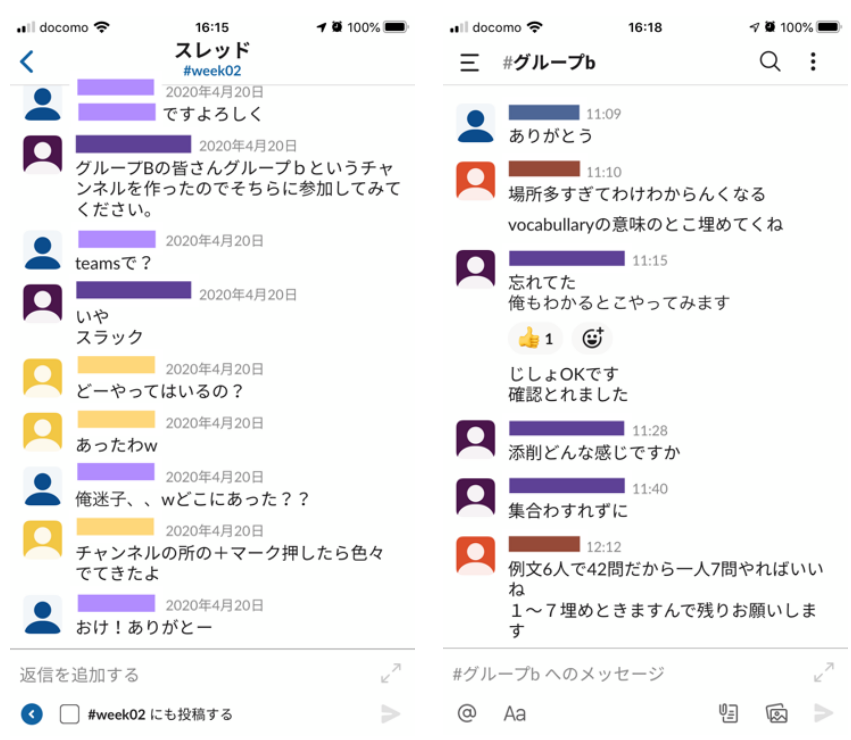

Figure 3: Cohesive Communication

To summarise, the various students' interactions are categorised in Table 2. They expressed emotion, self-disclosure, and humour; kept conversation going; expressed appreciation of others; and asked for help. They joined and left the workspace with greetings, showed commitment to their group, and shared their knowledge. Their interactions in Slack surely demonstrated all three categories of social presence in the virtual EFL classroom. 
Table 2: Social Presence Categories and Indicators

\begin{tabular}{|l|l|l|}
\hline Category & Indicators & Instances \\
\hline \multirow{4}{*}{$\begin{array}{l}\text { Interpersonal } \\
\text { communication }\end{array}$} & $\begin{array}{l}\text { Affective } \\
\text { expression }\end{array}$ & $\begin{array}{l}\text { Expressing apologies, appreciation, hesitation, empathy, } \\
\text { and sympathy }\end{array}$ \\
\cline { 2 - 3 } & Self-disclosure & $\begin{array}{l}\text { Presents personal life outside class, expresses } \\
\text { vulnerability }\end{array}$ \\
\cline { 2 - 3 } Open & Humour & Responding with a sense of humour \\
\cline { 2 - 3 } communication & Continuation & Replying to others' messages \\
\cline { 2 - 3 } & Agreement & Complimenting others and their contribution \\
\cline { 2 - 3 } & Questions & Asking questions to other students and the teacher \\
\hline Cohesive & Salutations & Greetings, closures \\
\cline { 2 - 3 } & Group solidarity & $\begin{array}{l}\text { Addressing the group as we, us, and our group, initiating } \\
\text { a group's channel, keeping group members updated by } \\
\text { sharing important issues }\end{array}$ \\
\hline
\end{tabular}

Note. Adapted from Garrison (2011: 38)

Group discussion sessions: Students gave constructive feedback in group discussion sessions, which covered three areas: system, class time, and communication. First, many students pointed out the complexity of using multiple systems and applications. It was revealed that quite a few of them were using only a smartphone to do all the class activities. While using Slack for group communication, they had to open, edit, and leave other applications. Some students said they had never used Blackboard Learn as a primary source of course information; some admitted difficulty in finding a new announcement.

Second, most students reacted positively to a synchronous mode of course delivery, while some preferred asynchronous offline coursework assignments. The former stated the enjoyment of realtime peer interaction. Some of them preferred to work on collaborative text-editing tasks during class time; otherwise, they would postpone and end up with not doing anything. Students who preferred an asynchronous mode claimed that they would learn more through individual work.

Finally, text-based communication seemed to have functioned both well and poorly, according to the aims of interaction. Slack workspaces helped students facilitate group work when the task required sharing a certain amount of information, such as links, files, and screenshots. While many agreed with the advantages of text-messaging that allowed them to leave and read comments when 
they are available, text-based communication was often dull and slow in terms of quick decisionmaking.

\section{Discussion}

The findings of this research generally demonstrated psychological closeness among students, which is associated with social presence in the virtual classroom (Blaine, 2019). In response to research question 1, the text-based peer interaction showed a variety of responses that indicated the three categories of social presence (Garrison, 2011). The students' feedback implied that the synchronous text-editing tasks could facilitate collaborative learning, which helped students feel connected with their group members as real people (d'Alessio et al., 2019; Gunawardena \& Zittle, 1997; Han \& Li, 2019). Students showed commitment to their groups when they socially interacted, mutually appreciated, and solved a problem without the teacher's involvement (Tuhkala \& Kärkkäinen, 2018). This finding partially answered research question 2, in that group communication through a text-messaging application could generally get the students engaged in collaborative knowledge construction (John-Steiner \& Mahn, 1996).

The data also implied three areas of difficulties that entailed the synchronous collaborative textbased tasks, which answered research question 3. The first area was technical issues. The use of multiple systems and applications required students, especially those who were using a smartphone, to frequently switch applications back and forth. Hyperlinks sometimes refused to work on some devices, which gave students choices to either ask for help or give up. Apart from the current urgent situation, the courses surely needed careful piloting before actual delivery. Second, text-based communication was good for project-based tasks; however, it was not suitable for tasks that needed quick decision-making. As Joksimović et al. (2015) demonstrated, tasks that assume constructive discussion could help to get students more engaged in collaborative learning activities. Finally, some students who preferred asynchronous course assignments might not feel comfortable with real-time communication-based tasks. This finding was in line with Kear et al.'s (2016) claim that some students' resistance to communicative online-learning tasks was not because of apathy but because of a disagreement between the collaborative learning tasks and their views on education. This finding could suggest a tension between traditional individual rote-learning and what sociocultural theory aims to achieve by social and transformative views on education (John-Steiner \& Mahn, 1996; Lantolf et al., 2015). 


\section{Conclusion}

The COVID-19 pandemic has brought about unprecedented school closures for extended periods. Educational isolation has deprived students of access not only to physical learning environments but also to social classroom communication, where they talk, laugh, solve a problem, and study together. This paper reported on a teacher's effort to get the students socially connected with each other in a virtual classroom. While the results suggested that the synchronous course delivery mode definitely had a place in putting students together as well as in maintaining and enhancing collaborative learning, they also revealed some technical difficulties as well as pedagogical issues that need to be addressed. Nevertheless, the researcher must admit that the students' social presence empowered herself as a teacher who had also been physically isolated from classroom teaching. The virtual classroom demonstrated the robustness of social and cultural communication, while keeping physical distancing rather than social distancing.

\section{Pedagogical implications:}

This study has three implications for pedagogical practices. First, careful task-planning is specifically important so as to increase the level of social presence in a virtual classroom (Joksimović et al., 2015). It is necessary to focus not only on the contents and outcomes of a task but also the types of information the task requires students to exchange. Next, adopting some asynchronous tasks could benefit students who prefer to work individually. Showing respect for their independence in learning could possibly make them feel more involved (Murphy et al., 2011). Lastly, effective instructional intervention remains essential. Teachers would play a crucial role in scaffolding students' skills for meaningful online interaction and building a supportive learning community (d'Alessio et al., 2019; Kear et al., 2016).

\section{Limitations and future research:}

The main limitation of this study is lack of concrete data collection methods like quantitative investigation into categorised online responses, structured questionnaire, and semi-structured interviews. It also did not include any data about learning outcomes. Future research could address these issues to illustrate a clearer picture of what types of interaction contribute to positive educational outcomes. It would also help to gain a more thorough understanding of how the feeling of connectedness affects learners' engagement in distance learning. In addition, this study had more or less relied on communicative classroom culture and some students' willingness to collaborate. In order to accommodate students with various learning preferences, hearing the voices of students 
who are unwilling to participate would be beneficial for future distance learning course development.

\section{Acknowledgments}

I deeply appreciate and thank Dr. Diamantidaki for her doctoral supervision at UCL Institute of Education and encouragements to stay focused even under challenging circumstances. I would like to thank two anonymous reviewers and Professor Robert J. Bonk for their insightful comments and suggestions on earlier drafts of the manuscript. My gratitude goes as well to Dr. Kefalaki for patiently accepting the very first draft despite this difficult time for all of us as educators around the world. 


\section{References}

Blaine, A. M. (2019). Interaction and presence in the virtual classroom: An analysis of the perceptions of students and teachers in online and blended Advanced Placement courses. Computers \& Education, 132, 31-43.

Cabinet Office (2020). Reiwa gan'nendo seishōnen no intānetto riyō kankyō jittai chōsa [Survey on the Internet environment for younger generation in fiscal year 2020]. Retrieved from https://www8.cao.go.jp/youth/youth-harm/chousa/r01/net-jittai/pdf/2-1-1.pdf

Chen, Q., \& Yan, Z. (2016). Does multitasking with mobile phones affect learning? A review. Computers in Human Behavior, 54, 34-42.

d'Alessio, M. A., Lundquist, L. L., Schwartz, J. J., Pedone, V., Pavia, J., \& Fleck, J. (2019). Social presence enhances student performance in an online geology course but depends on instructor facilitation. Journal of Geoscience Education, 67(3), 222-236.

Garrison, D. R. (2011). E-learning in the 21st century: A framework for research and practice. New York: Taylor \& Francis.

Gunawardena, C. N., \& Zittle, F. J. (1997). Social presence as a predictor of satisfaction within a computer-mediated conferencing environment. American journal of distance education, 11(3), 8-26.

Han, M., \& Li, Y. (2019). The effect of face-to-face and non-face-to-face synchronously collaborative writing environment on student engagement and academic performance. Journal of Education, Innovation, and Communication (JEICOM), 1(2), 65-74.

John-Steiner, V., \& Mahn, H. (1996). Sociocultural approaches to learning and development: A Vygotskian framework. Educational psychologist, 31(3-4), 191-206.

Joksimović, S., Gašević, D., Kovanović, V., Riecke, B. E., \& Hatala, M. (2015). Social presence in online discussions as a process predictor of academic performance. Journal of Computer Assisted Learning, 31(6), 638-654.

Kear, K., Jones, A., Holden, G., \& Curcher, M. (2016). Social technologies for online learning: theoretical and contextual issues. Open Learning: The Journal of Open, Distance and eLearning, 31(1), 42-53.

Lantolf, J. P., Thorne, S. L., \& Poehner, M. E. (2015). Sociocultural theory and second language development. In B, VanPatten, \& J, Williams (Eds), Theories in second language acquisition: An introduction (pp. 207-226). Abingdon: Routledge. 
MEXT (2001). Daigaku setchi kijun dai 25 jō dai 2 kō no kitei ni motozuki, daigaku ga rishū saseru koto ga dekiru jugyō-tō ni tsuite sadameru kudan [The matter of the establishment of the classes that universities provide, based on the provision of Article 25, Paragraph 2 of the University Establishment Standards]. Retrieved from https://www.mext.go.jp/b_menu/hakusho/nc/07091103/002.htm

MEXT (2020a). Reiwa 2-nendo ni okeru daigaku-tō no jugyō no kaishi-tō ni tsuite [About the start of classes at higher education institutions in fiscal year 2020]. Retrieved from https://www.mext.go.jp/content/20200324-mxt_kouhou01-000004520_4.pdf

MEXT (2020b). Daigakunado ni okeru shingata koronauirusukansenshō no kakudai bōshi sochi no jisshi ni saishite ryūi itadakitai jikō-tō ni tsuite [Regarding matters to be noted when implementing measures to prevent the spread of new coronavirus infectious diseases at higher education institutions]. Retrieved from https://www.mext.go.jp/content/20200420mxt_kouhou01-000004520_1.pdf

MEXT (2020c). Shingata koronauirusu kansenshō taisaku ni kansuru daigakunado no taiō jōkyō ni tsuite [About the correspondence situation at higher education institutions regarding $\begin{array}{lllll}\text { countermeasures } & \text { for } & \text { COVID-19 infection] } & \text { Retrieved }\end{array}$ https://www.mext.go.jp/content/20200413-mxt_kouhou01-000004520_2.pdf

MEXT (2020d). Shingata koronauirusu kansenshō taisaku ni kansuru daigakunado no taiō jōkyō ni tsuite [About the correspondence situation at higher education institutions regarding $\begin{array}{lllll}\text { countermeasures } & \text { for } & \text { COVID-19 infection] } & \text { Retrieved }\end{array}$ https://www.mext.go.jp/content/202000513-mxt_kouhou01-000004520_3.pdf

Ministry of Internal Affairs and Communication (2019). Heisei 30-nen tsūshin riyō dōkō chōsa no kekka [Results of 2018 communications usage trend survey]. Retrieved from https://www.soumu.go.jp/johotsusintokei/statistics/data/190531_1.pdf

Murphy, E., Rodríguez-Manzanares, M. A., \& Barbour, M. (2011). Asynchronous and synchronous online teaching: Perspectives of Canadian high school distance education teachers. British Journal of Educational Technology, 42, 583-591.

Palmer, S., Holt, D., \& Bray, S. (2008). Does the discussion help? The impact of a formally assessed online discussion on final student results. British Journal of Educational Technology, 39(5), 847-858.

Rehn, N., Maor, D., \& McConney, A. (2016). Investigating teacher presence in courses using synchronous videoconferencing. Distance Education, 37(3), 302-316. 
Tuhkala, A., \& Kärkkäinen, T. (2018). Using Slack for computer-mediated communication to support higher education students' peer interactions during Master's thesis seminar. Education and Information Technologies, 23(6), 2379-2397.

Vygotsky, L. S. (1978). Mind in society: The development of higher psychological processes. Cambridge, MA: Harvard university press.

Wei, F. Y. F., \& Wang, Y. K. (2010). Students' silent messages: Can teacher verbal and nonverbal immediacy moderate student use of text messaging in class?. Communication Education, 59(4), 475-496.

Witt, P. L., Wheeless, L. R., \& Allen, M. (2004). A meta-analytical review of the relationship between teacher immediacy and student learning. Communication Monographs, 71(2), 184207.

Zhang, X., Meng, Y., de Pablos, P. O., \& Sun, Y. (2019). Learning analytics in collaborative learning supported by Slack: From the perspective of engagement. Computers in Human Behavior, 92, 625-633. 